\title{
Comparative ecophysiology of Baltic and Atlantic Fucus vesiculosus
}

\author{
S. Bäck ${ }^{1}$, J. C. Collins ${ }^{2}$, G. Russel ${ }^{2}$ \\ ${ }^{1}$ University of Helsinki, Department of Botany, Unioninkatu 44, SF-00170 Helsinki, Finland \\ ${ }^{2}$ University of Liverpool, Department of Environmental \& Evolutionary Biology, PO Box 147, Liverpool L69 3BX, \\ United Kingdom
}

\begin{abstract}
A sublittoral population of Baltic Fucus vesiculosus L and an intertidal population from the Irish Sea have been compared in several aspects of ecophysiology under a wide range of short-term $(24 \mathrm{~h})$ salinity treatments ( 1.5 to $102 \mathrm{ppt}$ ). Both populations exhibited net photosynthesis over the range of salinity and in general Atlantic plants were more productive. Optimum salinity for photosynthesis was different for Baltic (6 ppt) and Atlantic (12 to $34 \mathrm{ppt}$ ) populations. There were no differences in total tissue water between the populations, but Atlantic plants contained a greater proportion of intracellular water. Salinity had an effect on the accumulation of osmotically active compounds and populations differed significantly in this respect; Atlantic contained higher ion and mannitol levels than Baltic. Both populations discriminated in favour of $\mathrm{K}$ in preference to $\mathrm{Na}$ and it seemed that $\mathrm{KCl}$ was the main inorganic solute responsible for osmotic balance. Based on ${ }^{42} \mathrm{~K}$ tracer experiments there was an unexchangeable pool of $\mathrm{K}$ in both populations. After short-term salinity exposure mannitol showed no clear increase in Baltic plants, however mannitol levels were higher after long-term exposure (11 wk, 1.5 to $45 \mathrm{ppt}$ ). In long-term experiments tissue ion contents were lower and differences in ionic relations were not so evident between the populations as compared to the short-term exposure data. Intraspecific differences in physiology of $F$. vesiculosus suggest that ecotypic differentiation has occurred to some extent between marine and brackish water populations.
\end{abstract}

\section{INTRODUCTION}

One of major abiotic factors controlling growth of algae is salinity. Algae growing in estuaries evidence the salinity changes from freshwater to full seawater. Intertidal or rockpool algae face salinity stress during periods of emersion depending on weather conditions. The most recent large-scale salinity change has happened in the Baltic Sea since the glacial period. The late-glacial and the post-glacial history of the Baltic Sea is one of alternating saltwater and freshwater episodes (West 1968, Ignatius et al. 1981). The last marine period occurred 7500 before present (BP) and that would have been the most likely time for marine flora recruitment to the Baltic. The present Baltic Sea is very young ( $3000 \mathrm{yr}$ ) and isolated from the Atlantic by its narrow exit, its non-tidal shores and its low, but locally quite stable salinity. Plants with unusual osmotic tolerances have been able to survive in the Baltic Sea and the boundaries of the species coincide more or less with their salt tolerance limits (Hartog 1967).
Comparative studies on algae populations from varying salinity regimes have suggested that there are intraspecific differences in osmoacclimation; for instance compared to marine populations, estuarine ones appear to be more resistant to extreme hyposaline stress and less resistant to hypersaline conditions (Reed \& Barron 1983, Young et al. 1987b). Reed \& Barron (1983) observed that there are differences in the relative importance of organic osmotica. Cellular mannitol concentration was significantly lower in estuarine Pilayella littoralis plants throughout a salinity range, as was the ion content; marine plants had higher ionic contents. They also measured cell turgor, which was found to be higher in marine plants. Young et al. (1987b) compared marine, rockpool and estuarine Enteromorpha intestinalis and found that the potassium levels within marine plants were higher than in their estuarine and rockpool counterparts and proposed the existence of ecotypes based on differences in the physiological responses in E. intestinalis. 
Despite numerous studies on the ionic relations and osmoadaptation of intertidal and estuarine algal populations there have been few studies on brackish water species such as those found in the Baltic. The most conspicuous alga of the sublittoral hard bottoms in the Baltic Sea is Fucus vesiculosus L. On the intertidal Atlantic shores it grows in the eulittoral zone but in the Baltic it is always submerged, because of lack of tides, ice scouring and protracted periods of low water levels in spring. Due to its geographic isolation and the unique hydrology of the Baltic Sea F. vesiculosus might have developed special physiological characteristics, which could be different from those of intertidal populations.

The main aims of this comparative study were: to measure the photosynthesis and respiration as possible indicators of salinity stress; to quantify the main components that restore turgor $(\mathrm{Na}, \mathrm{K}, \mathrm{Cl}$, mannitol); to test if populations are able to change their intracellular solute content in response to salinity treatment; to determine whether these populations, from contrasting environments, show any of the previously observed patterns of differences in estuarine dnci marine diyaé; and to study the long-term effects of osmotic stress on ion and organic solute accumulation.

\section{MATERIAL AND METHODS}

Plant material. Atlantic Fucus vesiculosus for shortterm experiments was collected from the exposed eulittoral zone on the NW side of Hilbre Island, River Dee, Cheshire, UK. Material for long-term experiments was obtained from the sheltered eulittoral zone of Derby Haven, Isle of Man, UK. Material was kept in running local-seawater tanks before being placed in plastic bags and transported in $3 \mathrm{~h}$ to Liverpool. Baltic plants for short-term and long-term experiments were collected from Brännskär, Tvärminne Archipelago, Gulf of Finland, SW Finland. After collection, material was maintained in seawater-filled buckets overnight, then packed into plastic bags and transferred to Liverpool in an insulated container. In the laboratory all plants were maintained in aerated filtered natural seawater (Atlantic, $34 \mathrm{ppt}$; Baltic, $6 \mathrm{ppt}$ ) at $10^{\circ} \mathrm{C}$ under a light regime of $100 \mu \mathrm{mol} \mathrm{m} \mathrm{m}^{-2} \mathrm{~s}^{-1}$ PAR (8 h light $16 \mathrm{~h}$ dark). Experiments were carried out as soon as possible after collection, and always within $10 \mathrm{~d}$. For all experiments material was cut from the apical $7 \mathrm{~cm}$ of the thallus

In short-term experiments plants were incubated in a range of salinities $(1.5,6,12,34,68,102 \mathrm{ppt})$ of artificial seawater medium A.SP12S without added vitamins (Reed et al. 1980a) for $24 \mathrm{~h}$ in continuous light $\left(100 \mu \mathrm{mol} \mathrm{m} \mathrm{m}^{-2} \mathrm{~s}^{-1}\right)$ at $10^{\circ} \mathrm{C}$ in $250 \mathrm{~cm}^{3}$ of media. Plant pieces of 0.1 to $0.2 \mathrm{~g}$ (fresh $\mathrm{wt}$ ) were cut for analysis. In long-term experiments diluted or concentrated natural seawater was used. Diluted media were obtained by diluting seawater with distilled water; concentrated seawater was obtained by evaporating natural seawater at 80 to $90^{\circ} \mathrm{C}$. Pieces of Fucus vesiculosus were cultivated for $12 \mathrm{wk}$ in $250 \mathrm{~cm}^{3}$ media in beakers with continuous aeration, media were changed and growth recorded once a week. Light conditions in long-term experiments were $100 \mu \mathrm{mol} \mathrm{m} \mathrm{m}^{-2} \mathrm{~s}^{-1},(8 \mathrm{~h}$ light: $16 \mathrm{~h}$ dark) and the temperature was $10^{\circ} \mathrm{C}$.

There are, however, problems which are encountered when studying the effects of low salinities on photosynthesis. One such problem is that the amount of dissolved carbon changes when media are diluted with distilled water and there is less $\mathrm{HCO}_{3}{ }^{-}$available for photosynthesis (Jolliffe \& Tregunna 1970). In general Baltic seawater has half the level of inorganic carbon compared to 35 ppt seawater (Raven \& Samuelson 1988). Also with decreasing salinity the concentrations of all ions decrease by the same ratio. So the question arises should dissolved carbon or certain ion concentiations be hept constant at normal sea water level during the experiment or should all components be diluted to obtain a certain salinity? In this study the approach was to mimic the changes in salinity as they might happen in nature by rainfall for instance. Thus it was decided to study the photosynthetic osmotic responses in natural Atlantic and Baltic seawaters without manipulating the $\mathrm{pH}$, dissolved carbon sources or individual ion concentrations.

Photosynthesis. Measurements of the net photosynthetic rate and dark respiration after $24 \mathrm{~h}$ incubation in well-aerated media of a wide range of salinities in saturating light were carried out using a Clark-type oxygen electrode (Hansatech). The electrode was calibrated using aliquots of oxygen-saturated media. Experiments were conducted at $10^{\circ} \mathrm{C}$ using a temperature-controlled water jacket around the chamber. Samples of clean material were placed in the chamber together with $2 \mathrm{~cm}^{3}$ of medium. For each population, rates were measured using 3 separate plants. Production or consumption of $\mathrm{O}_{2}$ was displayed on a chart recorder and rates calculated from the slope of an 8 to $10 \mathrm{~min}$ chart record and expressed as $\mathrm{mg} \mathrm{O}_{2} \mathrm{~h}^{-1}$ ( $g$ dry $w t)^{-1}$. Light was supplied from the halogen lamp of a slide projector. Light intensity was recorded by using a light meter placed behind the chamber unit. Dark respiration was measured by covering the reaction vessel completely with aluminium foil and black plastic

Water content. Tissue water content was determined by drying blotted preweighed fresh samples at $75^{\circ} \mathrm{C}$ to constant weight. Tissue water content was calculated as (fresh wt - dry wt)/fresh wt and ex- 
pressed as a percentage. Intracellular water content was calculated as (fresh wt) - (dry wt) - (extracellular water content). Extracellular water content was measured using ${ }^{14} \mathrm{C}$-mannitol assuming that exogenously supplied ${ }^{14} \mathrm{C}$-mannitol is not respired and enters the cell wall fraction only (Drew 1969, Diouris \& Floc'h 1984). Pieces of Fucus vesiculosus were incubated in different salinities for $24 \mathrm{~h}$. Pieces of $50 \mathrm{mg}$ were transferred to ${ }^{14} \mathrm{C}$-mannitol-labelled media for $20 \mathrm{~min}$ followed by a 30 min efflux into $1 \mathrm{~cm}^{3}$ unlabelled distilled water. A toluene/Triton X-100 based scintillation liquid was used for counting in a scintillation counter (United Technologies Packard, Minaxi, 4000 Series).

Chemical analyses. After incubation (as in photosynthetic work) plants were blotted and 5 replicates were washed for $10 \mathrm{~min}$ in $50 \mathrm{~cm}^{3}$ ice-cold $\mathrm{Ca}\left(\mathrm{NO}_{3}\right)_{2}$ solution isotonic with the treatment media. It was assumed that this procedure would remove cations bound to the cell wall. Plants were blotted dry and weighed. The dry weight was obtained after drying for $2 \mathrm{~d}$ at $75^{\circ} \mathrm{C}$. For $\mathrm{K}$ and $\mathrm{Na}$ analysis material was digested in $1 \mathrm{~cm}^{3}$ concentrated nitric acid (Aristar, $\mathrm{BDH}$ ) and the digest was diluted to $10 \mathrm{~cm}^{3}$. Ion concentrations were measured using a flame-emission spectrophotometer (Perkin Elmer). For tissue $\mathrm{Cl}$ concentrations, plant material was extracted in hot water for approximately $1 \mathrm{~h}$ after washing and weighing. $\mathrm{Cl}$ was determined by electrometric titration against $\mathrm{AgNO}_{3}$.

${ }^{42} \mathrm{~K}$ flux experiments. Plant material was incubated at the same temperature and light conditions as described previously. ${ }^{42} \mathrm{~K}$ was supplied by the University Research Reactor, Risley, Cheshire, UK, in the form of irradiated $\mathrm{K}_{2} \mathrm{CO}_{3}$. All media used in flux experiments were artificial seawater with the required concentration of $\mathrm{K}$ supplied by the $\mathrm{K}_{2} \mathrm{CO}_{3}$. The salinity range used in flux experiments was 1.5, 6, 12 and $34 \mathrm{ppt}$. Samples were aerated throughout the experiment. Samples were counted in a scintillation counter using Cherenkov radiation. Preweighed $50 \mathrm{mg}$ Fucus vesiculosus pieces were loaded in high specific activity ${ }^{42} \mathrm{~K}$ media of different salinities for $24 \mathrm{~h}$ in continuous light and $10^{\circ} \mathrm{C}$ as described previously. After equilibration 5 replicates were blotted dry and transferred through unlabelled media $\left(10 \mathrm{~cm}^{3}\right)$ of the same salinity at set time intervals. Wash samples and the $F$, vesiculosus pieces were counted at the end of the experiment.

The procedure for calculating the effluxes of ${ }^{42} \mathrm{~K}$ is based on the determination of rate constants for exchange of tracer between tissue and solution. These constants were used to calculate the potassium content in extracellular and intracellular compartments based on a biphasic model of efflux (Walker \& Pitman 1976).
The efflux of tracer can be calculated from the equation

$$
\theta=k Q^{\circ}
$$

where $\varnothing=$ the flux rate, nmol s$~^{-1}\left(\mathrm{~kg}\right.$ fresh $\mathrm{wt}^{-1} ; Q^{*}=$ cellular tracer content, nmol $(\mathrm{kg} \text { fresh } \mathrm{wt})^{-1} ; k=$ rate constant, $\mathrm{s}^{-1}$.

The separate rate constants for both phases were calculated from slopes individually for every replicate using simple linear regression analysis. The fast extracellular and slow cellular tracer contents, $Q_{\mathrm{f}}{ }^{*}$ and $Q_{\mathrm{s}}{ }^{*}$ respectively, were calculated by extrapolating the phases to zero.

Mannitol concentration. Quantitative analysis of tissue mannitol content was carried out, after $24 \mathrm{~h}$ incubation in a range of salinities, by gas-liquid chromatography. Amount of tissue used was 0.1 to $0.2 \mathrm{~g}$ (fresh wt). Quantification of mannitol was performed following extraction in $80 \% \mathrm{v} / \mathrm{v}$ ethanol. Boiling ethanol $\left(30 \mathrm{~cm}^{3}\right)$ was added and left for $20 \mathrm{~h}$ with continuous shaking at $40^{\circ} \mathrm{C}$. Another $20 \mathrm{~cm}^{3}$ boiling ethanol was then added and left for $2 \mathrm{~h}$ with shaking. The procedure given by Holligan \& Drew (1971) was followed in preparing samples for analysis. Samples were vacuum dried at $40^{\circ} \mathrm{C}$ and dissolved in $0.7 \mathrm{~cm}^{3}$ pyridine (including arabitol as an internal standardj. For derivatization $0.2 \mathrm{~cm}^{3}$ hexamethyldisilane (HMDS) and $0.1 \mathrm{~cm}^{3}$ trichloromethylsilane (TCMS) were used. Derivatized samples were shaken well and left to stabilise for $20 \mathrm{~h}$ in a desiccator and analysed the following day using a Philips series 304 gas-liquid chromatograph. Columns were packed with $2 \% \mathrm{w} / \mathrm{v}$ SE 52 on Diatomite CQ $80-100.2$ to $3 \mu \mathrm{l}$ of sample was injected onto the column. The temperature programme was as follows: column temperature 140 to $280^{\circ} \mathrm{C}$, increasing at a rate of $20^{\circ} \mathrm{C} \mathrm{min}-1$, holding the initial and final temperatures for $1 \mathrm{~min}$. Standards containing known amounts of mannitol were prepared and derivatized. From these a peak area vs concentration standard curve was calculated. Peak areas were recorded and quantified using a Philips CDP1 computing integrator.

\section{RESULTS}

\section{Photosynthesis and respiration}

For salinity treatment experiments a light intensity of $400 \mu \mathrm{mol} \mathrm{m} \mathrm{m}^{-2} \mathrm{~s}^{-1}$ was adopted. The effects of altered salinity on photosynthetic rates are shown in Fig. 1a. The net photosynthetic rates varied significantly in response to salinity and the rates varied also between the populations $(p \leq 0.001)$. In general Atlantic plants were more productive. Both populations exhibited differences in light-saturated photosynthetic responses 

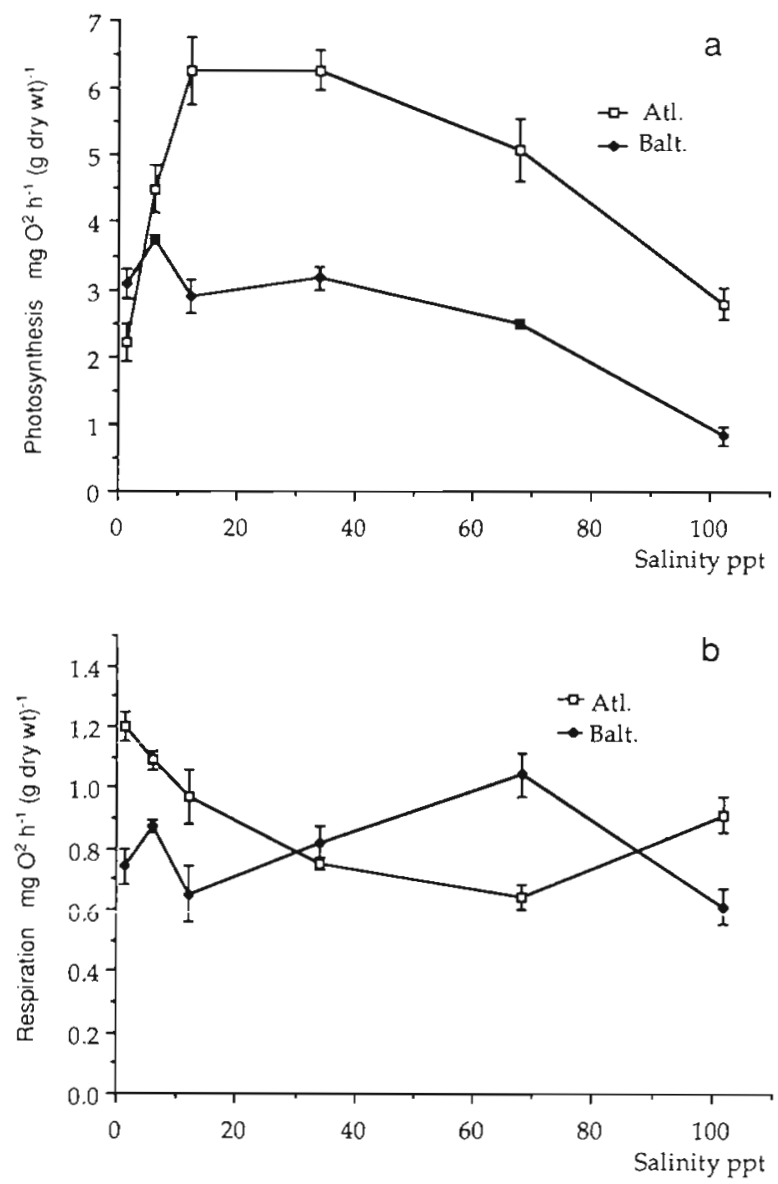

Fig. 1. Fucus vesiculosus. (a) Photosynthesis and (b) respiration of Atlantic and Baltic plants (mean \pm SE)

to salinity. The Baltic Fucus vesiculosus population had a clear peak of production in its normal seawater salinity of $6 \mathrm{ppt}$, and showed a steady decrease in $\mathrm{O}_{2}$ production in hypersaline treatments. In Atlantic plants there was clearly suppression at hypo- and hypersaline conditions and net photosynthesis reached its peak at 12 and $34 \mathrm{ppt}$.

Respiration of Atlantic Fucus vesiculosus was greatest at $1.5 \mathrm{ppt}$ declining with increasing salinity until reaching its minimum in $68 \mathrm{ppt}$. Baltic plants showed surprisingly high respiration rates in their normal seawater. However the highest respiration rates were obtained in $68 \mathrm{ppt}$ (Fig. 1b). Salinity had a highly significant effect on respiration of Atlantic plants $(p<0.001)$ in contrast to Baltic plants $(p<0.05)$.

\section{Water content}

Tissue water content of Baltic and Atlantic plants was inversely related to external salinity which had a
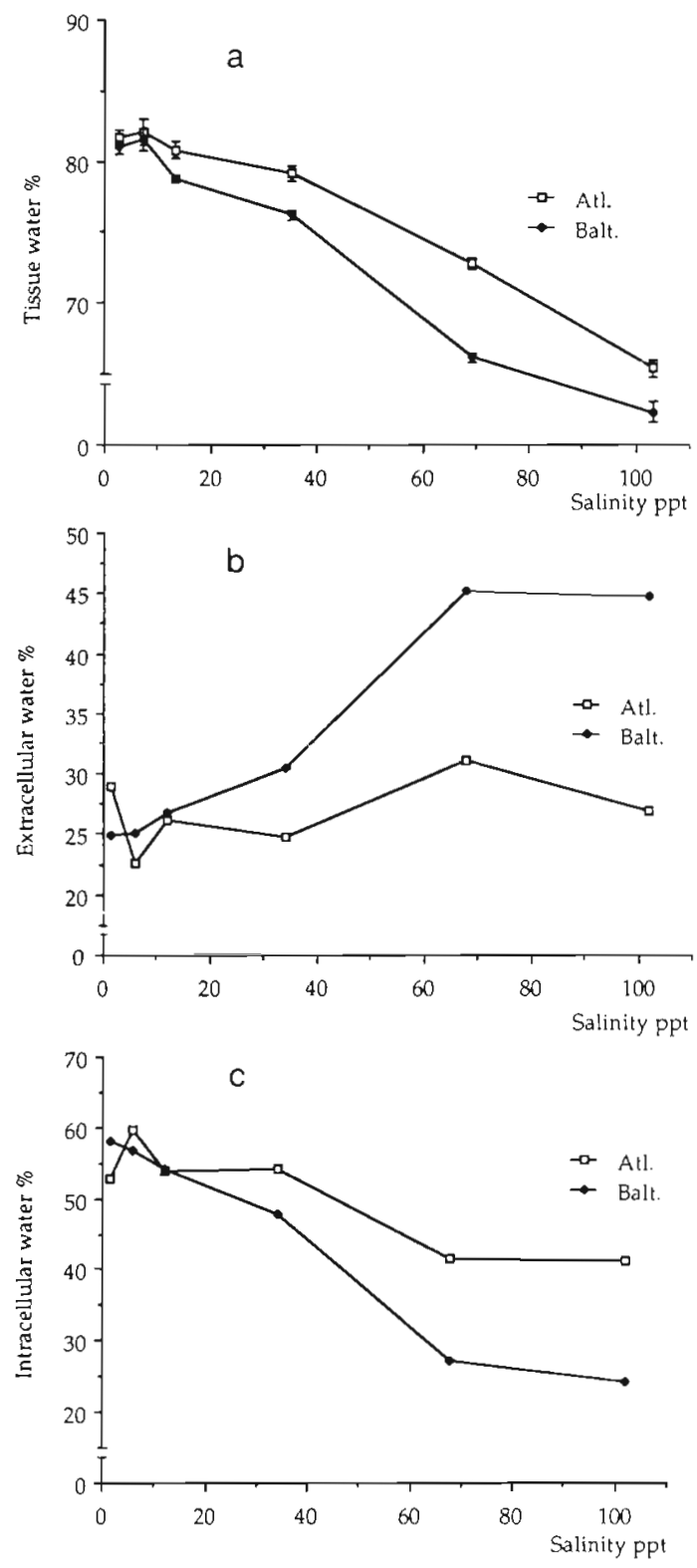

Fig. 2. Fucus vesiculosus. Variation of (a) tissue water, (b) extracellular water and $(c)$ intracellular water content of Atlantic and Baltic plants in different salinities (mean $\pm \mathrm{SE}$ )

highly significant effect on water content (Fig. 2a) and there were no significant differences between these 2 populations. Results from partitioning tissue water into intracellular and extracellular water are shown in Fig. 2b, c. Atlantic material showed a decrease in intracellular water content with increasing salinity, though the value in $1.5 \mathrm{ppt}$ salinity was surprisingly low. A very high percentage of water was present in the extracellular compartment (20 to $30 \%$ ). Similarly Baltic material showed a decrease in intracellular water content with increasing salinity. Compared to 
Atlantic material the decrease was greater in Baltic plants particularly in salinities above 34 ppt. In Baltic plants a greater percentage of thallus water was in the extracellular compartment. Approximately $25 \%$ of the tissue water was found as extracellular water in salinities below $12 \mathrm{ppt}$ and 30 to $45 \%$ was extracellular water in salinities above $34 \mathrm{ppt}$.

\section{Ionic relations}

The $\mathrm{K}$ content of Atlantic plants was significantly higher than in Baltic plants as were $\mathrm{Na}$ and $\mathrm{Cl}$ contents. In both populations $\mathrm{K}$ was the major cation. The $\mathrm{K}$ and $\mathrm{Cl}$ contents showed a similar pattern in both populations. There was a highly significant difference between populations, and salinity had an effect on ion content. For $\mathrm{K}$ content there was no interaction, so populations reacted in a similar manner to increasing salinity, thus there was a clear increase in tissue $K$ content in lower salinities and in higher salinities the response leveled off. In Atlantic plants $\mathrm{Cl}$ content leveled off in higher salinities, whereas Baltic plants showed a tendency to increase $\mathrm{Cl}$ content over the whole salinity range.

The total tissue contents calculated on the basis of tissue fresh wt for $\mathrm{Na}, \mathrm{K}$, and $\mathrm{Cl}$ were determined as a function of salinity (Fig. 3a, b, c). Tissue Na content was highly dependent on salinity and also there was a highly significant difference between populations (Table 1). Increase of $\mathrm{Na}$ in Atlantic plants was nearly linear with increasing salinity, whereas in Baltic plants $\mathrm{Na}$ levels decreased in salinities above $34 \mathrm{ppt}$.

Table 1. Fucus vesiculosus. ANOVA-table. Effect of population and salinity on total (tissue) content of $\mathrm{Na}, \mathrm{K}, \mathrm{Cl}$ and mannitol

\begin{tabular}{|lcccc|}
\hline \multirow{2}{*}{ Source of variation } & \multicolumn{4}{c}{ Significance level } \\
& $\mathrm{Na}$ & $\mathrm{K}$ & $\mathrm{Cl}$ & Mannitol \\
\hline $\begin{array}{l}\text { Population } \\
\text { Salinity }\end{array}$ & $\cdots$ & $\cdots$ & $\cdots$ & $\cdots$ \\
Population $\times$ Salinity & $\cdots$ & $\mathrm{NS}$ & $\cdots$ & $\cdots$ \\
NS: $\mathrm{p}>0.05_{i} \cdot \mathrm{p} \leq 0.05$, & $\cdots \mathrm{p} \leq 0.01$, & $\cdots$ & \\
\hline
\end{tabular}

Ion concentrations, based on intracellular water content, were estimated from the means of the measured contents and the calculated intracellular water values. The standard errors for these values were calculated using formulae adopted for cases involving sum or quotient (Worthing \& Geffner 1943). The general trend of the ion concentrations for both populations was an
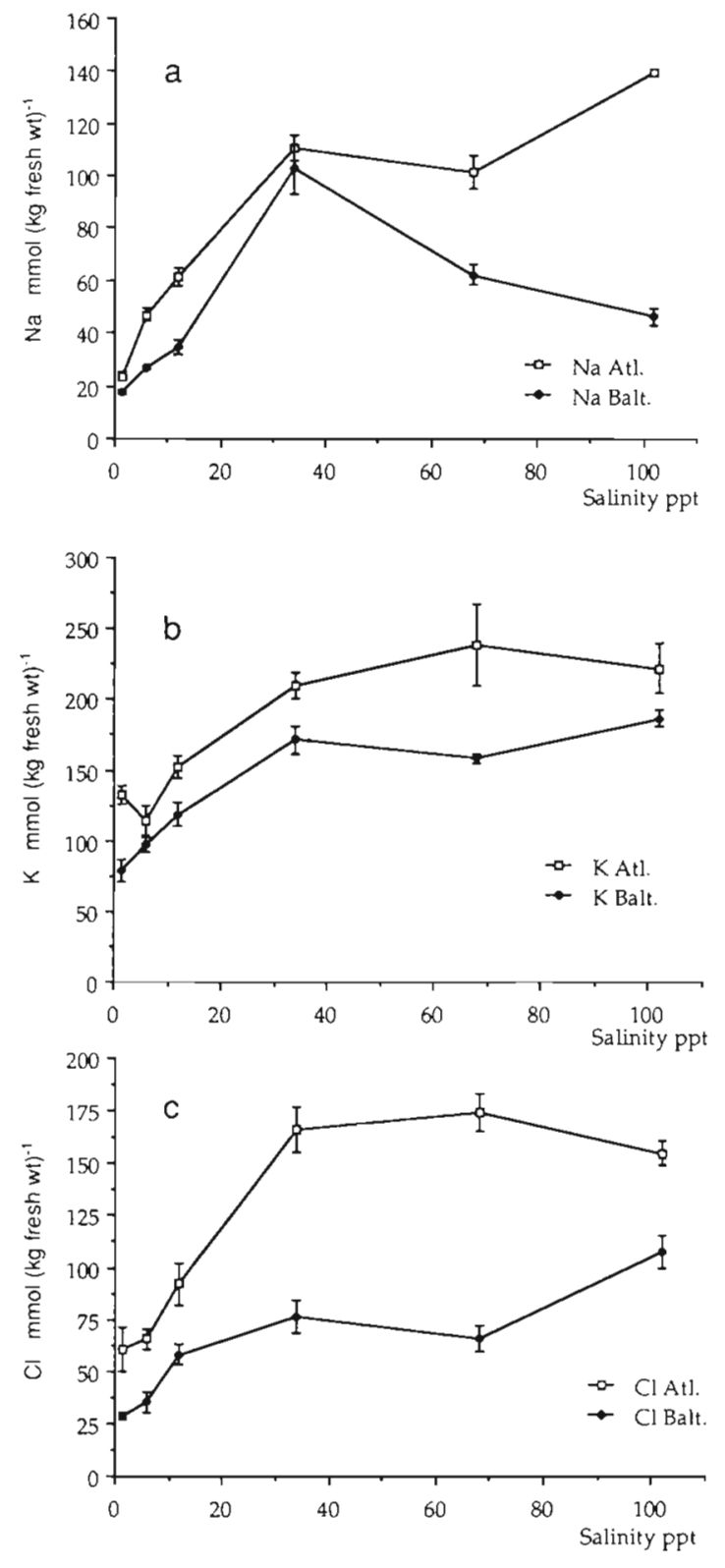

Fig. 3. Fucus vesiculosus. Total tissue content (mean $\pm \mathrm{SE}$ )

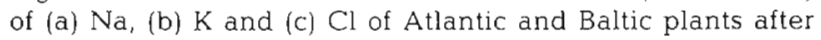
short-term $(24 \mathrm{~h})$ experiment in different salinities. Results expressed in terms of tissue fresh wt

increase in all ions with increasing salinity (Fig. 4a, b, c). The differences between populations except in $\mathrm{Cl}$ content were slight, though Atlantic plants still tended to have higher concentrations than their Baltic counterparts.

Because long-term salinity range was different (1.: to 45 ppt) from the short-term experiment and no determination of intracellular water was made, comparisons were possible only in terms of tissue fresh wt (Fig. 5a, b, c). The Na content of Baltic plants followed 

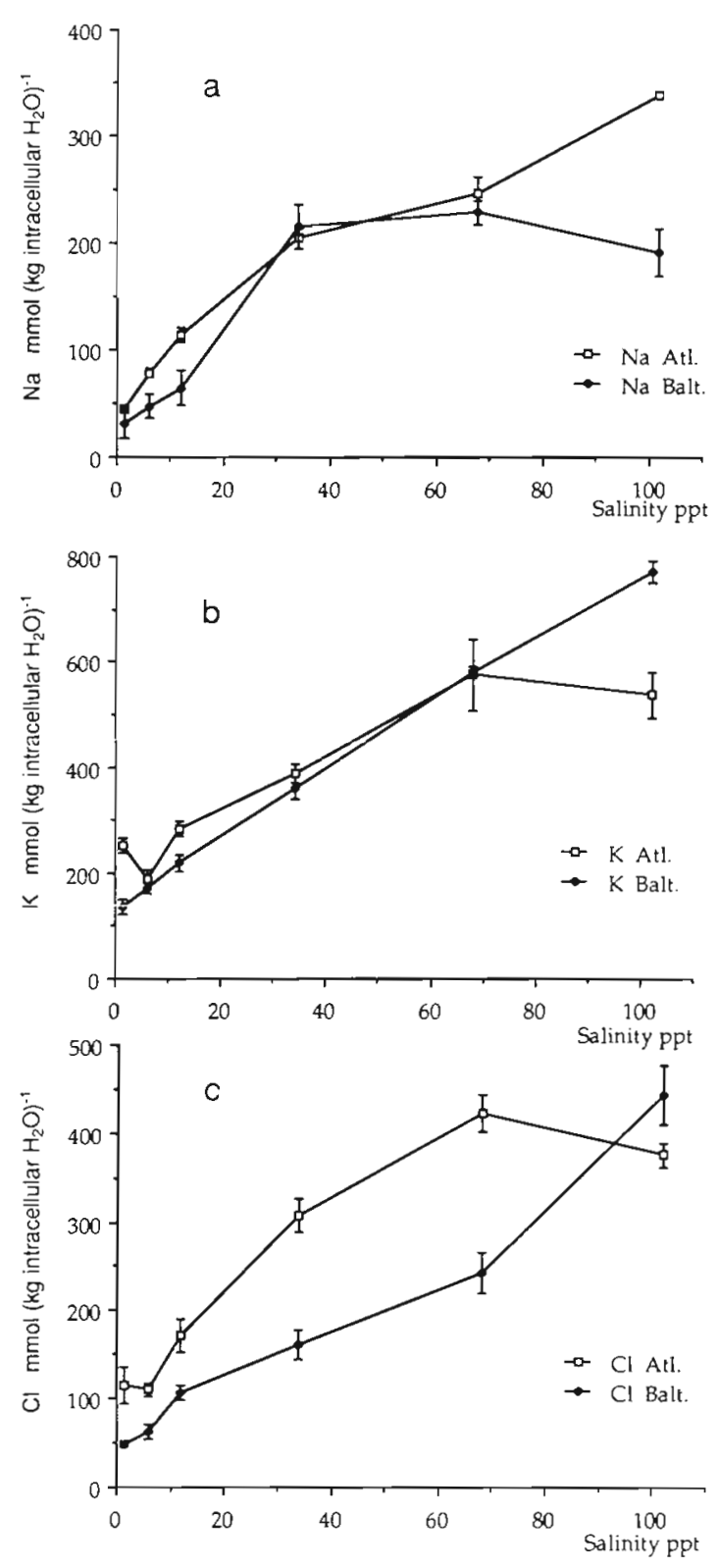

Fig. 4. Fucus vesiculosus. Total tissue content of (a) $\mathrm{Na}$, (b) $\mathrm{K}$ and (c) $\mathrm{Cl}$ (mean $\pm \mathrm{SE}$ ) of Atlantic and Baltic plants after short-term $(24 \mathrm{~h})$ experiment in different salinities. Results expressed in terms of intracellular water content

the same pattern as in short-term experiments. In Atlantic plants $\mathrm{Na}$ content leveled off in salinities above $12 \mathrm{ppt}$, whereas in the short-term $\mathrm{Na}$ increased in the tissue with increasing salinity. Thus there was a trend for tissue $\mathrm{Na}$ content to be much lower in the long-term.

Both populations demonstrated clear differences in $K$ content from short-term experiments. Atlantic plants still contained more $\mathrm{K}$ than their Baltic counterparts but $\mathrm{K}$ contents were much lower than in short-term
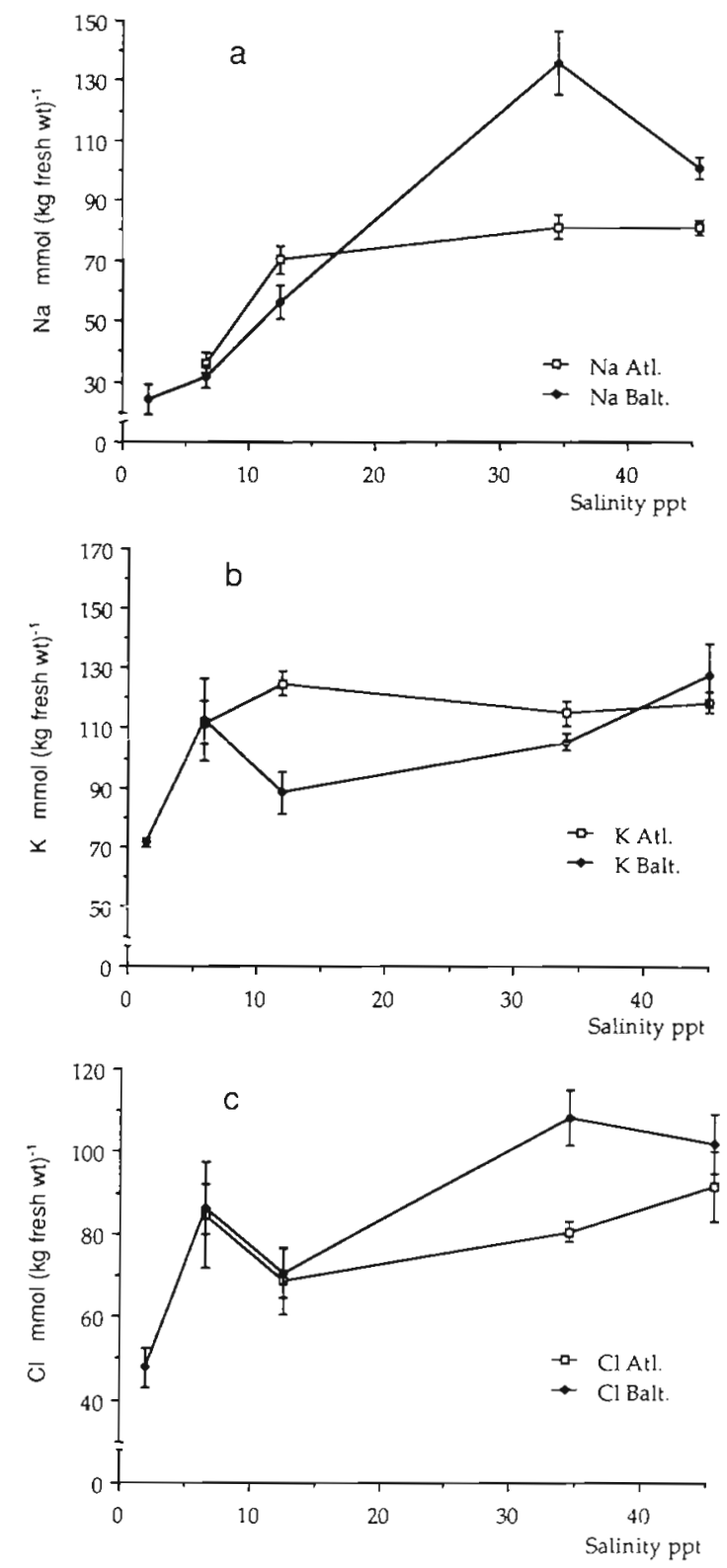

Fig. 5. Fucus vesiculosus. Total tissue content of (a) $\mathrm{Na}$, (b) $\mathrm{K}$ and $(\mathrm{c}) \mathrm{Cl}$ (mean $\pm \mathrm{SE}$ ) of Atlantic and Baltic plants after $11 \mathrm{wk}$ growth experiment in different salinities. Results expressed in terms of tissue fresh wt

experiments. The pattern of $\mathrm{Cl}$ content was similar between populations, though Atlantic plants contained less $\mathrm{Cl}$ than in short-term experiments.

\section{${ }^{42} \mathrm{~K}$ flux experiments}

Table 2 contains the results from radioisotope efflux experiments in different salinities. Extracellular and intracellular ion content calculated from 2 different 
phases are presented together with total ion content from chemical analysis. Cellular $K$ content formed a major fraction of the total tissue $K$ in all salinities, as there was very little adsorbed within cell walls. However it was obvious that between chemical and radioisotopic experiments there was not very good agreement for total ion content.

Table 3 shows data for efflux rates for both phases calculated on the basis of tissue fresh wt and intracellular water content. The fluxes from the fast phase $\left(\varrho_{i}\right)$ increased with salinity in both Atlantic and Baltic plants though the fluxes in Atlantic were somewhat higher. The slow phase $\left(\emptyset_{s}\right)$ fluxes also showed an increase with salinity, though this was nowhere near as clear as for the fast phase fluxes. Again the Atlantic $\varnothing_{s}$ tended to be greater than for Baltic plants, though this was not so marked as for $\emptyset_{i}$. The observed pattern of higher efflux rates of Atlantic plants agreed with the observations that cellular $K$ content was higher in Atlantic plants.

\section{Mannitol}

Concentrations of mannitol increased linearly with increasing salinity in Atlantic plants (Fig. 6a). There was a clear difference between populations, and salinity had an effect on mannitol accumulation (Table 1). Baltic mannitol levels were only half those of the Atlantic plants. However, the Baltic Fucus vesiculosus did not demonstrate any significant increase in tissue mannitol content in the higher salinities thus there is an interaction between populations and salinity. Calculated on the basis of intracellular water content Atlantic plants still contained higher concentrations of mannitol than Baltic plants (Fig. 6b). However, it is clear that Baltic plants do show an increase of mannitol concentration with increasing salinity.

The long-term effects of salinity on mannitol accumulation differed from those previously described for short-term treatments (Fig. 6c). In both populations there was a linear increase in mannitol as salinity

Table 2. Fucus vesiculosus. Mean (SE) $\mathrm{K}$ content $\left(Q_{\mathrm{f}}{ }^{*}\right.$ : extracellular; $Q_{\mathrm{s}}{ }^{*}$ : cellular) of Baltic and Atlantic plants in different salinities estimated by chemical and radioisotopic methods. All values are expressed in mmol ( $\mathrm{kg}$ fresh wt) ${ }^{-1}$

\begin{tabular}{|c|c|c|c|c|c|c|c|c|c|c|}
\hline \multirow[t]{2}{*}{$\begin{array}{l}\text { Salinity } \\
\text { (ppt) }\end{array}$} & \multicolumn{2}{|c|}{$Q_{\mathrm{f}}$} & \multicolumn{2}{|c|}{$Q_{s}{ }^{\circ}$} & \multicolumn{2}{|c|}{$\begin{array}{c}Q^{*} \text { total } \\
\text { radioisotopic }\end{array}$} & \multicolumn{2}{|c|}{$\begin{array}{l}Q \cdot \text { total } \\
\text { chemical }\end{array}$} & \multicolumn{2}{|c|}{$\% \mathrm{~K}$ unexchangeable } \\
\hline & Atlantic & Baltic & Atlantic & Baltic & Atlantic & Baltic & Atlantic & Baltic & Atlantic & Baltic \\
\hline 1.5 & $\begin{array}{c}3.1 \\
(0.2)\end{array}$ & $\begin{array}{l}5.0 \\
(0.3)\end{array}$ & $\begin{array}{l}27.3 \\
(1.3)\end{array}$ & $\begin{array}{l}24.8 \\
(2.3)\end{array}$ & $\begin{array}{l}30.1 \\
(1.2)\end{array}$ & $\begin{array}{l}29.8 \\
(2.4)\end{array}$ & $\begin{array}{r}132.8 \\
(6.6)\end{array}$ & $\begin{array}{l}78.9 \\
(8.0)\end{array}$ & 77 & 62 \\
\hline 6 & $\begin{array}{c}8.2 \\
(1.4)\end{array}$ & $\begin{array}{c}6.9 \\
(1.2)\end{array}$ & $\begin{array}{l}75.3 \\
(4.1)\end{array}$ & $\begin{array}{l}59.2 \\
(4.1)\end{array}$ & $\begin{array}{l}83.8 \\
(2.9)\end{array}$ & $\begin{array}{l}66.1 \\
(4.5)\end{array}$ & $\begin{array}{l}113.3 \\
(10.7)\end{array}$ & $\begin{array}{l}97.2 \\
(6.1)\end{array}$ & 26 & 31 \\
\hline 12 & $\begin{array}{c}7.9 \\
(1.2)\end{array}$ & $\begin{array}{c}9.0 \\
(0.8)\end{array}$ & $\begin{array}{l}64.0 \\
(4.1)\end{array}$ & $\begin{array}{l}67.3 \\
(2.3)\end{array}$ & $\begin{array}{l}72.0 \\
(3.6)\end{array}$ & $\begin{array}{l}76.4 \\
(2.8)\end{array}$ & $\begin{array}{r}152.4 \\
(7.9)\end{array}$ & $\begin{array}{r}118.6 \\
(8.8)\end{array}$ & 52 & 35 \\
\hline 34 & $\begin{array}{l}22.7 \\
(2.1)\end{array}$ & $\begin{array}{l}20.6 \\
(0.5)\end{array}$ & $\begin{array}{r}165.6 \\
(5.9)\end{array}$ & $\begin{array}{l}96.1 \\
(5.9)\end{array}$ & $\begin{array}{c}188.3 \\
(7.1)\end{array}$ & $\begin{array}{r}116.9 \\
(6.5)\end{array}$ & $\begin{array}{r}209.8 \\
(8.8)\end{array}$ & $\begin{array}{c}171.0 \\
(3.2)\end{array}$ & 10 & 31 \\
\hline
\end{tabular}

Table 3. Fucus vesiculosus. Mean (SE) efflux rates $\left(\varnothing_{\mathrm{f}}\right.$ : extracellular; $\varnothing_{\mathrm{s}}$ : cellular) of Baltic and Atlantic plants expressed in terms of both tissue fresh wt and intracellular water content

\begin{tabular}{|c|c|c|c|c|c|c|}
\hline \multirow[t]{2}{*}{$\begin{array}{l}\text { Salinity } \\
\text { (ppt) }\end{array}$} & \multicolumn{2}{|c|}{$\begin{array}{c}\varnothing_{\mathrm{f}} \\
\mathrm{nmol} \mathrm{s}{ }^{-1}(\mathrm{~kg} \text { fresh } \mathrm{wt})^{-1}\end{array}$} & \multicolumn{2}{|c|}{$\frac{\varnothing_{\mathrm{s}}}{\mathrm{nmol} \mathrm{s}{ }^{-1}(\mathrm{~kg} \text { fresh } \mathrm{wt})^{-1}}$} & \multicolumn{2}{|c|}{$\begin{array}{c}\varnothing_{\mathrm{s}} \\
\mathrm{nmol} \mathrm{s}{ }^{-1} \\
\left(\mathrm{~kg} \text { cellular } \mathrm{H}_{2} \mathrm{O}\right)^{-}\end{array}$} \\
\hline & Atlantic & Baltic & Atlantic & Baltic & Atlantic & Baltic \\
\hline 1.5 & $\begin{array}{r}1683 \\
(180)\end{array}$ & $\begin{array}{l}1534 \\
(147)\end{array}$ & $\begin{array}{r}194 \\
(20)\end{array}$ & $\begin{array}{l}229 \\
(20)\end{array}$ & $\begin{array}{l}336 \\
(38)\end{array}$ & $\begin{array}{l}394 \\
(34)\end{array}$ \\
\hline 6 & $\begin{array}{r}4339 \\
(104)\end{array}$ & $\begin{array}{l}3214 \\
(648)\end{array}$ & $\begin{array}{r}1270 \\
(149)\end{array}$ & $\begin{array}{r}1098 \\
(128)\end{array}$ & $\begin{array}{l}2125 \\
(250)\end{array}$ & $\begin{array}{l}1945 \\
(225)\end{array}$ \\
\hline 12 & $\begin{array}{l}5706 \\
(237)\end{array}$ & $\begin{array}{l}3966 \\
(353)\end{array}$ & $\begin{array}{r}959 \\
(77)\end{array}$ & $\begin{array}{l}579 \\
(36)\end{array}$ & $\begin{array}{r}1780 \\
(140)\end{array}$ & $\begin{array}{r}1068 \\
(66)\end{array}$ \\
\hline 34 & $\begin{array}{r}15223 \\
(616)\end{array}$ & $\begin{array}{l}8410 \\
(425)\end{array}$ & $\begin{array}{r}4412 \\
(32)\end{array}$ & $\begin{array}{r}1087 \\
(53)\end{array}$ & $\begin{array}{r}8165 \\
(56)\end{array}$ & $\begin{array}{l}2277 \\
(111)\end{array}$ \\
\hline
\end{tabular}



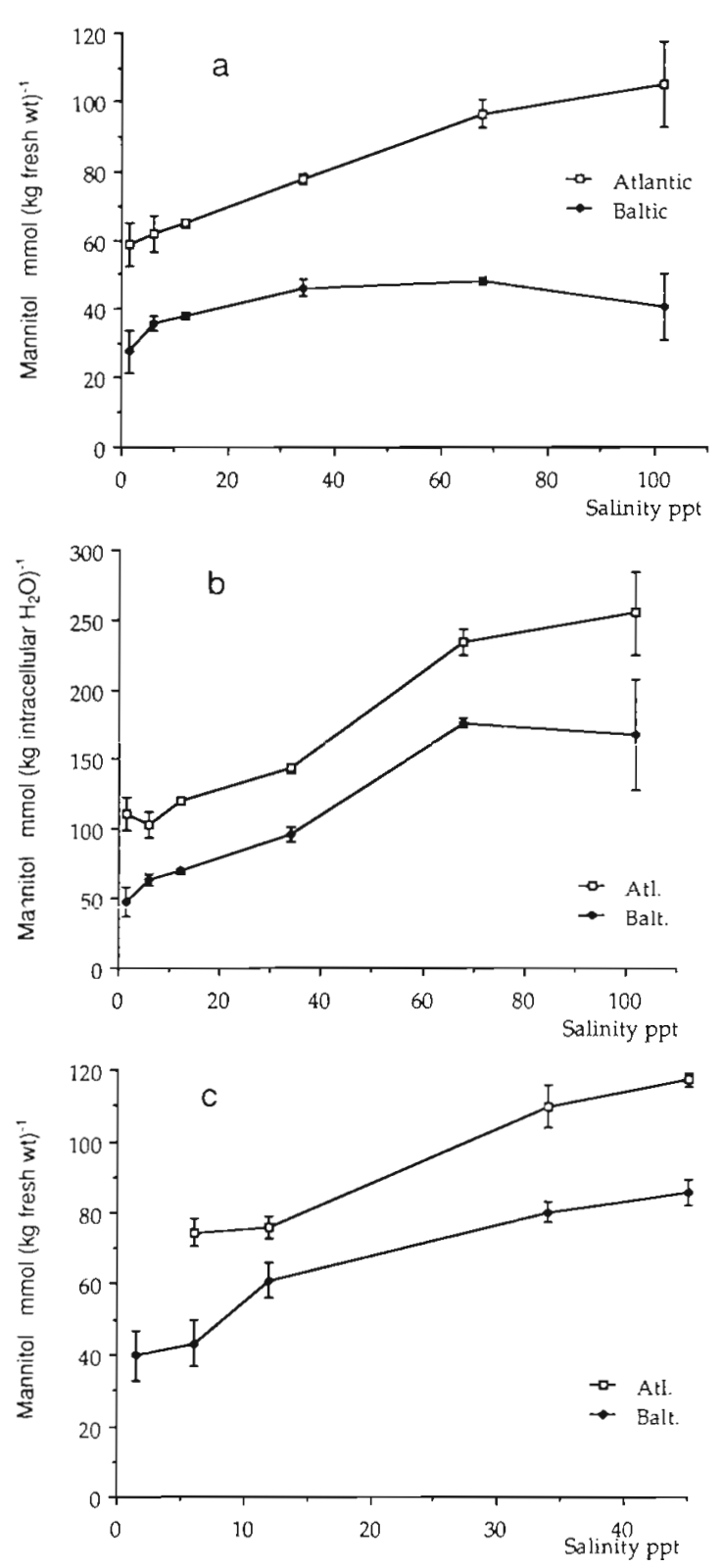

Fig. 6. Fucus vesiculosus. Mannitol content (mean $\pm \mathrm{SE}$ ) of Atlantic and Baltic plants in different salinities: (a) after shortterm $(24 \mathrm{~h})$ experiment, results in terms of tissue fresh wt; (b) after short-term experiment, results in terms of intracellular water; and (c) after long-term culture experiment, results in terms of tissue fresh wt

increased. The levels of mannitol, as before, were higher in Atlantic than Baltic plants. However, the levels of mannitol were considerably higher after the long-term experiments, especially in the Baltic material.

Normal Atlantic seawater has an osmolality of ca $1070 \mathrm{mOsmol} \mathrm{kg} \mathrm{kg}^{-1}$ and the Baltic seawater of ca 189 mOsmol kg-1 (Table 4). If the total intracellular
Table 4. Fucus vesiculosus. Total content of osmotically active compounds measured in Atlantic and Baltic plants

\begin{tabular}{|c|c|c|c|}
\hline \multirow[t]{2}{*}{ (ppt) } & \multirow[t]{2}{*}{$\begin{array}{l}\text { Salinity } \\
\qquad\left(\mathrm{mOsmol} \mathrm{kg}^{-1}\right)\end{array}$} & \multicolumn{2}{|c|}{$\begin{array}{c}\mathrm{Na}+\mathrm{K}+\mathrm{Cl}+\text { mannitol } \\
\text { (mOsmol kg-1 intracellular } \mathrm{H}_{2} \mathrm{O}\end{array}$} \\
\hline & & Atlantic & Baltic \\
\hline 1.5 & 47 & 520 & 260 \\
\hline 6 & 189 & 477 & 344 \\
\hline 12 & 377 & 699 & 458 \\
\hline 34 & 1070 & 1042 & 828 \\
\hline 68 & 2140 & 1472 & 1225 \\
\hline 102 & 3210 & 1504 & 1574 \\
\hline
\end{tabular}

concentrations measured for $\mathrm{Na}, \mathrm{K}, \mathrm{Cl}$ and mannitol are added up they would account for 200 to $300 \mathrm{mmol}$ $\mathrm{kg}^{-1}$ more than external osmotic pressure in salinities below 12 ppt. For salinities above 68 ppt for Atlantic plants and above 34 ppt for Baltic, measured internal solutes accounted for only 40 to $50 \%$ of the external osmolality. A positive turgor pressure is predicted in the Atlantic material in hyposaline treatment and up to $34 \mathrm{ppt}$, whereas for Baltic material turgor is positive up to 12 ppt. I lowever, it must be remembered that this analysis takes no account of sugars, amino acids and other ions.

\section{DISCUSSION}

As general responses of algae to salinity, the growth rate and survival or photosynthetic and respiration rates have been studied most frequently (Gordon et al. 1980, Reed et al. 1980b, Yarish \& Edwards 1982, Smith \& Berry 1986, Koch \& Lawrence 1987, Russell 1987. Bäck et al. 1992). The net photosynthetic responses of Atlantic and Baltic populations of Fucus vesiculosus to salinity showed that both populations have a wide salinity range. Both exhibit net photosynthetic gain between 1.5 and 102 ppt; the Atlantic population has an optimum between 12 to $34 \mathrm{ppt}$ and the Baltic population at 6 ppt. The reduction of photosynthetic rate for Atlantic F. vesiculosus plants in 1.5 and 102 ppt and in higher salinities for Baltic plants demonstrates that salinity does have an effect on photosynthesis. This is contrary to the observations by Reed et al. (1985) who found only a minor variation in the photosynthetic rate of F. serratus in the salinity range of 7 to $50 \mathrm{ppt}$.

Many algal species exhibit the ability to photosynthesise over a broad salinity range, usually showing optimal photosynthesis in a certain range of salinity. Gracilaria verrucosa showed a positive photosynthetic response over a range of salinity, with a marked decrease in net photosynthesis below 10 and above 40 ppt, and optimum being between 20 and 30 ppt (Dawes et al. 1978). G. tikvahiae showed broad toler- 
ance limits for net photosynthetic response between 5 and $40 \mathrm{ppt}$ (Penniman \& Mathieson 1985). An optimal range can be defined as those salinities causing minimal osmotic stress and permitting the highest photosynthetic rates. Ogata \& Schramm (1971) and Ohno (1976) reported depressed photosynthetic rates in Porphyra umbilicalis especially in hypersaline conditions and Thomas et al. (1988) showed that both freshand brackish water populations of Cladophora species exhibited very little tolerance to higher salinities based on studies of net photosyntesis.

The Fucus vesiculosus populations showed significantly different responses in dark respiration rates. The responses of Atlantic plants followed the trends shown by Ogata \& Takada (1968) for some intertidal species in that the respiratory rate increases in hyposaline media. Similarly Dawes et al. (1978) reported high respiratory rates for intertidal and subtidal species after exposure to extreme hyposaline conditions. In general the observations in this study support the findings of Wilkinson (1980) that photosynthesis decreases and the rates of respiration increase at low salinities, leading to reductions in net photosynthesis.

Due to the complexity of the thallus structure of Fucus vesiculosus, partitioning the tissue water into intracellular and extracellular compartments cannot be accepted without question. Normally extracellular water content has been measured after exposures of about 2 min to ${ }^{14} \mathrm{C}$-labelled media (Reed 1980, Reed et al. 1980a, 1985), but in our study the time used was 20 min due to the complexity of tissue and to allow external ${ }^{14} \mathrm{C}$-mannitol uptake to level off. Also the possibility of intracellular accumulation, even of seemingly negligible amounts of mannitol, could lead to overestimation of the extracellular water. However, the calculated intracellular water content values appear to give reliable trends between populations. Reed et al. (1985) gave values of water partitioning of Atlantic $F$. vesiculosus which are in reasonable agreement with the values from our study. Despite a similar response between the populations it is worth noting that the changes in intracellular water vs salinity are greater in plants from the Baltic than from the Atlantic. A similar pattern was observed by Reed \& Barron (1983) where estuarine Pilayella littoralis had a greater intracellular water content than marine material.

All ion contents were calculated in the terms of both tissue fresh wt and intracellular water content to make comparison of values easier with those existing in the literature. Davison \& Reed (1985a) found a K concentration of $499 \mathrm{mmol} \mathrm{\textrm {kg } ^ { - 1 }}$ in Laminaria digitata from normal seawater. This is somewhat higher than the

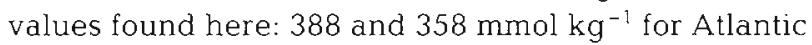
and Baltic Fucus vesiculosus respectively. However,

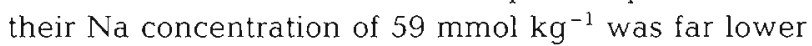

than that found in our Atlantic (204 mmol $\mathrm{kg}^{-1}$ ) or Baltic (214 mmol $\mathrm{kg}^{-1}$ ) plants.

It is obvious that both the Baltic and Atlantic Fucus vesiculosus discriminate in favour of $\mathrm{K}$ in preference to $\mathrm{Na}$ and it seems that $\mathrm{KCl}$ is the main inorganic solute responsible for osmotic balance. $\mathrm{K}$ is sufficient to balance about $25 \%$ in Baltic plants and about $30 \%$ in Atlantic plants of the external solute concentration in 34 ppt seawater (calculated from radioisotopic experiments). Both populations of $F$. vesiculosus fall into the category of algae having $K$ as the main cation (Kirst 1990). This is a common feature of many marine algae (Raven 1976, Kirst \& Bisson 1979); it is speculated that these species' turgor pressure is regulated by changing the activity of a $\mathrm{K}$ pump. Kirst \& Bisson (1979) found members of the Phaeophyta, e.g. Eclonia and Dictyota, to have high intracellular $\mathrm{K}$ concentrations. Similarly Young et al. (1987b) reported that Enteromorpha intestinalis has high $\mathrm{K}$ levels with very low intracellular Na values, though the Na levels in the cell wall were high. Reed \& Collins (1980) found that Porphyra purpurea has most of its $\mathrm{Na}$ in the cell wall. In the present study $\mathrm{Na}$ content was measured after a 10 min wash in $\mathrm{Ca}\left(\mathrm{NO}_{3}\right)_{2}$ which is assumed to remove extracellular ions, however such a simple procedure is unlikely to be totally efficient and probably gives a large overestimate of intracellular $\mathrm{Na}$ and thus accurate $\mathrm{Na}$ flux data are needed. If the intracellular $\mathrm{Na}$ values here do epresent a serious overestimate, then $\mathrm{KCl}$ is even more important as an internal solute. Certainly $\mathrm{Na}$ values of at least $200 \mathrm{mmol} \mathrm{kg}{ }^{-1}$ cell water seem much too high (Flowers \& Läuchli 1983); also $\mathrm{K}$ values seem to be quite high.

Another common phenomenon, an anion deficit, was evident. The amount of $\mathrm{Cl}$ alone can not be responsible for all negative charges in the cell but it has been shown to be the main anion. In studies by Winter et al. (1987) and Young et al. (1987a) other anions such as $\mathrm{SO}_{4}{ }^{2-}, \mathrm{HPO}_{4}{ }^{2-}$ have far lower concentrations than $\mathrm{Cl}$. Marine Fucus vesiculosus plants contain significantly higher amounts of $\mathrm{Cl}$ than their brackish water counterparts. In both populations $\mathrm{Cl}$ content is dependent on salinity.

Both Atlantic and Baltic Fucus vesiculosus showed biphasic $\mathrm{K}$ efflux. But there is great variation of the initial fast phase duration which could be related to the structure of the algae. The physical locations of the 2 phases of $\mathrm{K}$ efflux are difficult to ascribe. It has been assumed that the initial fast phase $\left(t_{1 / 2}=30 \mathrm{~min}\right)$ comes from extracellular films and intercellular spaces and the cell walls. The $t_{1 / 2}$ is long compared with values found by Ritchie \& Larkum (1985) and Young et al. (1987a) ( $t_{1 / 2}<5 \mathrm{~min}$ ) for Enteromorpha intestinalis. It is also assumed that this is a reflection of the complexity of the multi-layered, leathery-like tissue of $F$. vesicu- 
losus as well as the copious mucus in the hyphae that is present. It is assumed that the slow second phase is intracellular in origin (Ritchie \& Larkum 1985, Young et al. 1987a). The location of phases is difficult, and in the end may not be feasible. But certainly more experimentation is required in an effort to locate various ions in the $F$. vesiculosus thallus. Monophasic effluxes are found in Porphyra purpurea (Reed \& Collins 1980, 1981) and E. intestinalis (Ritchie \& Larkum 1985). However, they found biphasic intracellular exchange in low salinity grown $E$. intestinalis plants. The $\mathrm{K}$ efflux of Laminaria digitata (Davison \& Reed 1985a) is monophasic after an initial rapid phase. The efflux from the intracellular slow phase is $2.9 \mu \mathrm{mol}(\mathrm{kg} \text { fresh } \mathrm{wt})^{-1} \mathrm{~s}^{-1}$ in normal seawater, this is only $65 \%$ of the efflux observed in Atlantic F. vesiculosus [4.4 $\mu \mathrm{mo}$ ] (kg fresh $w t)^{-1} s^{-1}$ ] and nearly 3 times the value for Baltic plants $\left[1.0 \mu \mathrm{mol}\left(\mathrm{kg}\right.\right.$ fresh $\left.\mathrm{wt}^{-1} \mathrm{~s}^{-1}\right]$. Reed (1984b) gives values of $\mathrm{K}$ efflux for Polysiphonia lanosa from marine and estuarine sites and when expressed with respect to plasmalemma surface area the $K$ efflux is greater in marine plants whereas flux rates, expressed in terms of ccllular water content, are similar. In this present study plasmalemma surfaces have not been calculated, but the tendency of lower $\mathrm{K}$ flux rates was noticeable in Baltic plants for rates expressed in terms of cellular water.

In the Fucales mannitol has been found to be the main organic compound involved in osmoacclimation, varying as a direct function of salinity in all cases in the brown algae studied. It would seem that the role of mannitol as an 'osmotic compatible solute' is clear (Reed et al. 1985, Davison \& Reed 1985b). In both short-term and long-term experiments mannitol levels increases in Atlantic plants whereas in Baltic plants the increases in mannitol levels were much more obvious only in long-term experiments. Similarly Reed (1983) found that organic solutes, e.g. di-methylsulphoniopropionate (DMSP), formed a greater proportion of the internal osmotic potential of marine plants than of estuarine plants of Polysiphonia lanosa. A similar pattern was observed with mannitol content, where marine plants contained nearly 1.5 or double the level of mannitol that was found in brackish plants under the same conditions. In our study mannitol counterbalances a relatively small component of the external osmotic potential; it is relatively more important under hyposaline conditions (20\% of external salinity) than hypersaline $(10 \%)$. Also mannitol seems to play a less important role in Baltic plants, where ions play a correspondingly greater role.

Both populations contained more mannitol after long-term exposure to salinity. Mannitol synthesis is rapid (McLachlan \& Bidwell 1978), and for cellular functioning it is better to maintain a positive turgor pressure by means of organic solutes. These solutes usually exhibit some protective functions and they are generally less harmful to cellular metabolic function and enzyme activity than ions (Davison \& Reed 1985b, Edward et al. 1988). The short-term experiment might have been too short to reach full mannitol adaptation, though $24 \mathrm{~h}$ is surely a reasonable period allowing for tidal cycles in nature. In the Baltic Sea Fucus vesiculosus does not experience tidal and short-term salinity changes and thus short-term mannitol production does not increase with increasing external salinity.

Broady et al. (1984) and Gibson et al. (1984) have shown that ribosome stability in an in vitro translation of $\mathrm{m}$-RNAs is salt sensitive for a wide range of plants. Levels of $\mathrm{K}$ above $125 \mathrm{mM}$ started to cause inhibition and polysomes were also less stable in the presence of $\mathrm{Cl}$ than organic ions such as acelate. Similarly $\mathrm{Na}$ was more inhibitory than $\mathrm{K}$. The intracellular levels reported here for all these ions ( $K, N a$ and $C l)$ seem markedly high. However, such seemingly high ionic levels have often been reported (Davison \& Reed 1985a, Young et al 1987b, Thomas et al. 1989) for marine algae. Also it is noteworthy that long term ion levels are much lower than those found in the short term.

There were clear differences in ion and mannitol content between populations calculated on tissue fresh weight. Atlantic plants had consistently higher contents. This pattern was observed before when the same species from fully marine habitats and from estuarine locations were compared (Reed \& Barron 1983). They observed that the cellular mannitol concentration was significantly lower in estuarine Pilayella littoralis plants throughout a salinity range, and that there were higher ion levels in the marine plants as well.

It has been suggested that the wide salinity distribution of some species might be due to different 'osmotic strategies' (Young et al. 1987b) and osmoadaptation (Reed 1984a, b) has occurred. The presence of different strategies within a species might lead to the existence of ecotypes (Turesson 1922). The main question for this study was that are there differences between brackish and marine plants? The experimental data show clearly that there are consistent differences between populations in photosynthetic responces, intracellular water content, accumulation of ions and the organic solute mannitol. All these intraspecific differences in physiology suggest that ecotypic differentiation has occurred to some extent and has led to ecotypes of Fucus vesiculosus from marine and brackish water populations which live under completely different saline environments and regimes.

Acknowledgements. The authors thank the technical staff at Port Erin Marine Laboratory and Tvärminne Zoological Station for help during the sampling. This work was supported by the Academy of Finland through a research grant to S.B. 


\section{LITERATURE CITED}

Bäck, S., Collins, J. C., Russell, G. (1992). The effects of salinity on growth of Baltic and Atlantic Fucus vesiculosus. Br. Phycol. J. 27: 39-47

Broady, C. J., Gibson, T. B., Barlow, E. W. R., Spiers, J., WynJones, R. G. (1984). Salt tolerance in plants. I. Ions, compatible organic solutes and the stability of plant ribosomes. Plant Cell Environ. 7: 571-578

Davison, I. R., Reed, R. H. (1985a). Osmotic adjustment in Laminaria digitata (Phaeophyta) with particular reference to seasonal changes in internal solute concentrations. J. Phycol. 21: 41-50

Davison, I. R., Reed, R. H. (1985b). The physiological significance of mannitol accumulation in brown algae: the role of mannitol as a compatible cytoplasmic solute. Phycologia 24: 449-457

Dawes, C. J., Moon, R. E., Dawis, M. A. (1978). The photosynthetic and respiratory rates and tolerances of benthic algae from a mangrove and salt marsh estuary: a comparative study. Estuar. coast. mar. Sci. 6: 175-185

Diouris, I. R., Floc'h, J. (1984). Long-distance transport of ${ }^{14} \mathrm{C}$ labelled assimilates in the Fucales: directionality, pathway and velocity. Mar. Biol. 78: 199-204

Drew, E. A. (1969). Uptake and metabolism of exogenously supplied sugars by brown algae. New Phytol. 68: 35-43

Edwards, D. M., Reed, R. H., Stewart, W. D. P. 11988) Osmoacclimation in Enteromorpha intestinalis: long-term effects of osmotic stress on organic solute accumulation. Mar. Biol. 98: 467-476

Flowers, T J., Läuchli, A. (1983). Sodium versus potassium: substitution and compartmentation. In: Läuchli, A., Bieleski, R. L. (eds.) Encyclopedia of plant physiology. New series, Vol. 15B. Inorganic plant nutrition. SpringerVerlag, Berlin, p. 651-681

Gibson, T S, Spies, J., Brady, C. J. (1984). Salt tolerance in plants. II. In vitro translation of m-RNAs from salt-tolerant and salt-sensitive plants on wheatgerm ribosomes. Responces to ions on compatible organic solutes. Plant Cell Environ. 7: 579-587

Gordon, D. M., Bird, P. B., McComb, A. J. (1980). The effect of light, temperature and salinity on photosynthesis rates of an estuarine Cladophora. Bot. Mar. 23: 749-755

Hartog, C. den. (1967). Brackish water as an environment for algae. Blumea 15: 29-43

Holligan, P. M., Drew, E. A. (1971). Routine analysis by gasliquid chromatography of soluble carbohydrates in extracts of plant tissues. II. Quantative analysis of standard carbohydrates, and the separation and estimation of soluble sugars and polyols from a variety of plant tissues. New Phytol. 70: 271-297

Ignatius, H., Axberg, S., Niemistö, L., Winterhalter, B. (1981). Quaternary geology of the Baltic Sea. In: Voipio, A. (ed.) The Baltic Sea. Elsevier, Amsterdam, p. 54-69

Jolliffe, E. A., Tregunna, E. B. (1970). Studies on $\mathrm{HCO}_{3}$-ion uptake during photosynthesis in benthic marine algae. Phycologia 9: 293-303

Kirst, G. O. (1990). Salinity tolerance of eukaryotic marine algae. Ann. Rev. Plant Physiol. Plant. Mol. Biol. 41: 21-53

Kirst, G. O., Bisson, M. A. (1979). Regulation of turgor pressure in marine algae: ions and low-molecular-weight organic compounds. Aust. J. Plant Physiol. 6: 539-556

Koch, E. W., Lawrence, J. (1987). Photosynthetic and respiratory responses to salinity changes in the red alga Gracilaria verrucosa. Bot. Mar. 30:327-329

McLachlan, J. L., Bidwell, R. G. R. (1978). Photosynthesis of eggs, sperm, zygotes and embryos of Fucus serratus.
Can. J. Bot. 56: 371-373

Ogata, E., Schramm, W. (1971). Some observations on the influence of salinity on growth and photosynthesis in Porphyra umbilicalis. Mar. Biol. 10: 70-76

Ogata, E., Takada, H. (1968). Studies on the relationship between the respiration in some marine plants in Japan. J. Shimonoseki Coll. Fish 16: 67-88

Ohno, M. (1976): Some observations on the influence of salinity on photosynthesis activity and chloride ion loss in several seaweeds. Int. Revue Gesamten Hydrobiol. 61: 665-672

Penniman, C. A., Mathieson, A. C. (1985). Photosynthesis of Gracilaria tikvahiae McLachlan (Gigartinales, Rhodophyta) from the Great Bay estuary, New Hampshire). Bot. Mar. 28: $427-435$

Raven, J. A. (1976). Transport in algal cells. In: Luttge, U., Pitman, M. G. (eds.) Encyclopedia of plant physiology. Transport in plants. IIA. Cells. New series, Vol. 24A. Springer-Verlag, Berlin, p. 129-188

Raven, J. A., Samuelson, G. (1988). Ecophysiology of Fucus vesiculosus $\mathrm{L}$. close to its northern limit in the Gulf of Bothnia. Bot. Mar. 31: 399-410

Reed, R. H. (1980). The influence of salinity upon cellular mannitol concentration of the euryhaline marine alga Pilayella littoralis (L.) Kjellm. (Phaeophyta, Ectocarpales): Preliminary observations. Bot. Mar. 23: 603-605

Reed, R. H. (1983). Measurement and osmotic significance of b-dimethyl-sulphoniopropionate in marine macroalgae. Mar. Biol. Lett. 4: 173-181

Reed, R. H. (1984a). Use of asmoterminology. Plant Cell Environ. $7: 165-170$

Reed, R. H. (1984b). The effects of extreme hyposaline stress upon Polysiphonia lanosa (L.) Tandy from marine and estuarine sites. J. exp. mar. Biol. Ecol. 76: 131-144

Reed, R. H., Barron, J. A. (1983). Physiological adaptation to salinity change in Pilayella littoralis from marine and estuarine sites. Bot. Mar. 26: 409-416

Reed, R. H., Collins, J. C. (1980). The ionic relations of Porphyra purpurea (Roth) C.Ag. (Rhodophyta, Bangiales). Plant Cell Environ. 3: 399-407

Reed, R. H., Collins, J. C. (1981). The kinetics of $\mathrm{Rb}^{+}$and $\mathrm{K}^{+}$ exchange in Porphyra purpurea. Plant Sci. Lett. 20: $281-289$

Reed, R. H., Collins, J. C., Russell, G. (1980a). The effects of salinity upon cellular volume of the marine red alga Porphyra purpurea (Roth) C.Ag. J. exp. Bot. 31: 1521-1537

Reed, R. H., Collins, J. C., Russell, G. (1980b). The influence of variations in salinity upon photosynthesis in the marine alga Porphyra purpurea (Roth) C.Ag. (Rhodophyta Bangiales). Z. PflPhysiol. 98: 183-187

Reed, R. H., Davison, I. R., Chudek, J. A., Foster, R. (1985). The osmotic role of mannitol in the Phaeophyta: an appraisal. Phycologia 24: 35-47

Ritchie, R. J., Larkum, A. W. D. (1985). Potassium transport in Enteromorpha intestinalis (L.) Link. I. Measurement of intracellular $\mathrm{K}^{+}$exchange fluxes and thermodynamic analysis. J. exp. Bot. 36: 63-78

Russell, G. (1987). Spatial and environmental components of evolutionary change: interactive effects of salinity and temperature on Fucus vesiculosus as an example. Helgoländer Meeresunters. 41:371-376

Smith, C. M., Berry, J. A. (1986). Recovery of photosynthesis after exposure of intertidal algae to osmotic and temperature stresses: comparative studies of species with different distributional limits. Oecologia 70: 6-12

Thomas, D. N., Collins, J. C., Russell, G. (1988). Interactive effects of temperature and salinity upon net photosynthesis of Cladophora glomerata (L.) Kütz. and C. ru- 
pestris (L.) Kütz. Bot. Mar. 31: 73-77

Thomas, D. N., Collins, J. C., Russell, G. (1989). Photosynthetical responses to salt stress of two ecologically different Cladophora species. Bot. Mar. 32: 259--265

Turesson, G. (1922). The genotypical response of the plant species on the habitat. Hereditus 3: 21.1-250

Walker, N. A., Pitman, M. G. (1976). Measurement of fluxes across membranes. In: Lüttge, U., Pitman, M. G. (eds.) Encyclopedia of plant physiology. New series, Vol. IIa. Springer-Verlag, Berlin, p. 93-129

West, R. G. (1968). Pleistocene geology and biology. Longman, Harlow, p. 377

Winter, U., Meyer, M. I. B., Kirst G. O. (1987). Seasonal changes of ionic concentrations in the cellular sap of Chara vulgaris L. growing in a brackish water lake Oecologia 74: 122-127

This article was submitted to the editor
Wilkinson, M. (1980). Estuarine benthic algae and their environment: a review. In: Price, J. H., Irvine, D. E. G., Farnham, W. F. (eds.) The shore environment. Vol. 2 Ecosystems. Academic Press, London. p. 425-286

Worthing, A. G., Geffner, J. (1943). Treatment of experimental data. Wiley \& Sons, London, p. 342

Yarish, C., Edwards, P. (1982). A field and cultural investigation of the horizontal and seasonal distribution of estuarine red algae of New Jersey. Phycologia 21. $112-124$

Young, A. J., Collins, J. C., Russell, G. (1987a). Solute regulation in the euryhaline marine alga Enteromorpha prolifera (O.F.Müli.) J.Ag. J. exp. Bot. 38: 1298-1308

Young, A. J., Collins, J. C., Russell,, G. (1987b). Ecotypic variation in the osmotic responses of Enteromorpha intestinalis (L.) Link. J. exp. Bot. 38: 1309-1324

Manuscript first received: November 1, 1991

Revised version accepted: April 28, 1992 